\title{
マイクロ波放電式イオンエンジン用耐久試験装置の開発*1 Development of an Endurance Test Facility for Microwave Discharge Ion Engine System
}

\author{
船木一幸*2 國 中 均*2 ・都木恭一郎*2 ・清 水幸夫*2・佐 鳥 新*2,*3 \\ Ikkoh Funaki, Hitoshi Kuninaka, Kyoichiro ToKI, Yukio Shimizu and Shin SAToRI
}

Key Words : Electric Propulsion, Ion Engine, Endurance Test, Vacuum Chamber

\begin{abstract}
In order to take advantage of electric propulsion for a rendezvous with a near-earth small body such as a commet or an asteroid, very long continuous thruster operation of several years is required. For the asteroid sample and return mission named MUSES-C, the institute of space and astronautical science is developing a new-concept ion engine, microwave discharge ion engine, whose cathode-less discharge chamber made the engine being free from the degradation of the electrodes. To demonstrate the new thruster's lifetime, a full-automated test facility was constructed and the endurance test of the ion engine started in February 1997. The facility consists of a large vacuum chamber evacuated by cryogenic pumps and a thruster system; the latter includes a propellant feed system, microwave power generators, power supply units for ion acceleration, and a data acquisition system. All the engine operation system is integrated into a GPIB bus interface and safely controled by computers without any on-site personnel.
\end{abstract}

\section{1.はじめに}

イオンエンジンは Hughes Space and Communications 社が開発した通信衛星 PanAmSat-5の成功て、いよいよ 商業利用の段階に入った Hughes-XIPS 13 や宇宙開発事業団と三菱電機が共同で 開発したイオンエンジンは静止衛星の南北軌道保持が目的 である2,3).すなわち，イオンエンジンによって 3000 秒前 後の高比推力を $50 \%$ 程の推進効率で発生させ, 低推力な がらもそれを長期間にわたって運用することで化学推進機 での軌道保持に対して大きなペイロードメリットを出す. このような静止軌道保持への利用に一応の目処がついたこ とで, 現在のイオンエンジン開発は第二段階へ進んでお り，太陽電池を電力源にした電気推進機による惑星間航行 (Solar-Electric-Propulsion, SEP) の実現へ向けた計画が 展開中である．SEP は低コスト宇宙ミッションの重要な 技術として認識されており，イオンエンジンを始めとする 電気推進機の搭載により, 打ち上げコストの低減とミッシ ョン時間の短縮が同時に実現可能となる4).スイングバイ やエアロブレーキが使えない状況ではSEP のメリットは 特に大きく、これはNASAが 98 年 10 月に打ち上げた小 惑星フライバイミッションDeep Space 1 (DS-1) に搭載 されたイオンエンジン NSTAR (NASA's Solar Electric Propulsion Technology Applications Readiness) 計画に 代表される4,5). 日本においても文部省宇宙科学研究所が

\footnotetext{
*1 平成 11 年 3 月 4 日原稿受理

*2 宇宙科学研究所

${ }^{* 3}$ 現在, 北海道工業大学
}

開発中の小惑星サンプルリターン衛星 MUSES-C (Mu Space Engineering Satellite C) にて SEP が検証され $ろ^{6)}$.

イオンエンジンの動作原理自体は極めて簡単である。推 進㓮を電離して生成したイオンを, 高電圧を引加したグリ ッド電極にて静電的に加速噴射して推力を得る7).しかし これを寒現するには主イオンの加速やプラズマ生成のため 最低 $6 \supset$ 電源が必要であり, $1 \mathrm{kV}$ 以上の高電圧がかか る静電加速用グリッドを始めとして, 高温ヒータ, 流量制 御器など，非常に多くの制御部位を持つ、現にNASAに おけるイオンエンジン開発でも，世界初の長期作動宇宙試 験を行ったSERT-II (Space Electric Rocket Test-II) から, 開発途中で搭載中止となったIAPS (Ion Auxiliary Propulsion System) 家経て NSTAR, XIPSへと続く 30 年にもわたる研究開発が成果をあげており，逆に言え ば㬰用までこれだけ多くの時間を要したという事実が，た くさんのコンポーネントを持ったイオンエンジンに起こり 得る不具合対策を設計にフィードバックさせ，信頼性を高 めていくことがいかに難しいかを物語っている，直流放電 型イオンエンジンの中枢技術である，プラズマを作り出す ホローカソードと呼ばれる電極を含む主放電室と, グリッ ドと呼ばれるイオンビーム抽出加速系，これら二つの技術 は骨格は 60 年代後半には既に完成していた。それでもイ オンエンジンが普及しなかったのは，電気推進機の中でも とりわけ多くの機器を構成要素として持ち, 全体としての 信頼性が不確定だったためである.イオンエンジンの技術 はスラス夕性能の向上もさることながら，スラス夕や周辺 機器の信頼性や耐久性向上のため何度も改良を加えられ, 
現在の形に至ったと言えよう。こうしたフィードバックは エンジンの長期耐久試験の中でこそ可能になる。なぜな ら，どのような故障モードがエンジンシステムの中に存在 するかは，最終的に実時間の長期耐久試験にて検証するし かないからである．低推力であるイオンエンジンは長期間 運用することで初めて化学推進機を凌ぐことができる．従 ってイオンエンジンの実用化を進める上で，長期耐久性を 検証する技術は必須である。

イオンエンジンシステム全体の信頼性を上げる努力は， 各部位の信頼性向上と, システム簡略化の努力の歴史でも ある. 宇宙科学研究所の提唱するマイクロ波放電型イオン エンジンは，マイクロ波放電を利用することでシステムの 抜本的な簡略化を行い，エンジンの寿命要因の一つである 直流放電による熱電極起因の主放電室内のコンタミを根本 的に取り除いた ${ }^{8}$ ．運転ロジックも簡単であり，一切の余 熱を必要としない. 以下には，このマイクロ波イオンエン ジンの概略を述べると共に，新規に製作した耐久試験設備 と，イオンエンジンの初期試験結果について報告する.

\section{MUSES-C 計画と主推進機用イオンエンジン}

はじめに小惑星探査衛星 MUSES-C 搭載用イオンエン ジンの概要について述べる. MUSES-C は, 自律航法に 基づいた小惑星へのランデブー, 小惑星表面のサンプル採 取，そして地球へのサンプル持ち㷌りといった一連のミッ ションに必要な新規技術を検証する工学衛星である゙ 惑星のような微小天体へのランデブーでは，スイングバ イ・エアロキャプチャーによる加速・隇速ができず，ま た，フライトも長期間に渡ることから，低推力・高比推力 を特徵とする電気推進機を連続運用することで化学推進機 に比へて大きな力積を出し，メリットを発揮することがで きる.エンジンは直方体衛星構体の一面に設置され，4台 搭載の $400 \mathrm{~W} / 7 \mathrm{mN}$ 級イオンエンジンが 3 台まで同時作 動し, 合計 $21 \mathrm{mN}$ 以上の推力を出す予定である. 小惑星 へのタッチダウン時など瞬時に $\Delta V$ が必要な局面では化 学推進機の出番となるが, 探査機の惑星間巡行フェースに 必要な $\Delta V$ のほとんどを電気推進機にて受け持つことに なっている。

マイクロ波イオンエンジンは第 1 図のような構成であ る.エンジン1台あたりで見ると、イオンビームを噴射す るスラスタヘッド，ビームによる衛星の帯電を防ぐための 中和器, スラスタヘッド及び中和器の双方へマイクロ波を 供給するマイクロ波電源，イオンビームを加速する直流電 源、そして，スラスタヘッドと中和器の双方に推進削を供 給する推進片供給系と、これら全てを制御する制御系から なる。

$\mathrm{EM}$ スラスタヘッドの概略図が第 2 図に示してある、エ ンジン放電室内へは予めキセノン推進郕を一定流量で供給 しておき，そこへマイクロ波が同軸ケーブル・アンテナ・ 円形導波管を介して主放電室に導かれると，磁石表面付近

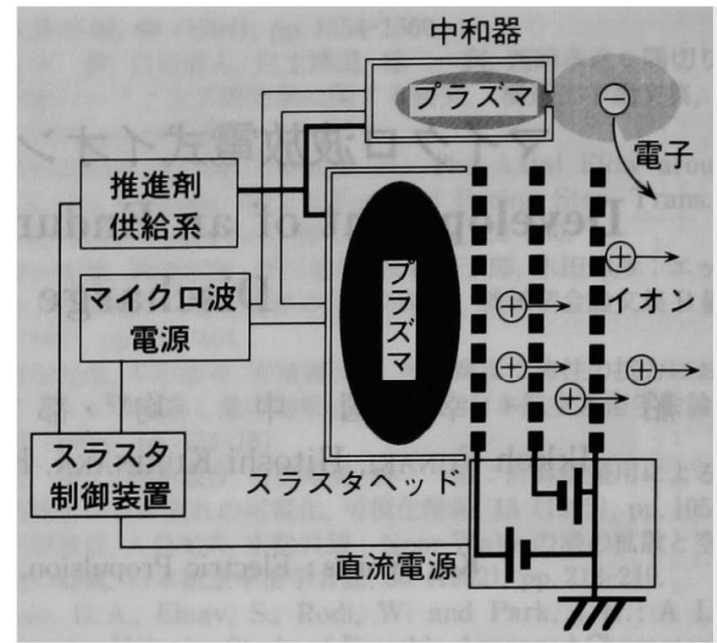

第 1 図 マイクロ波イオンエンジンの基本䊤成

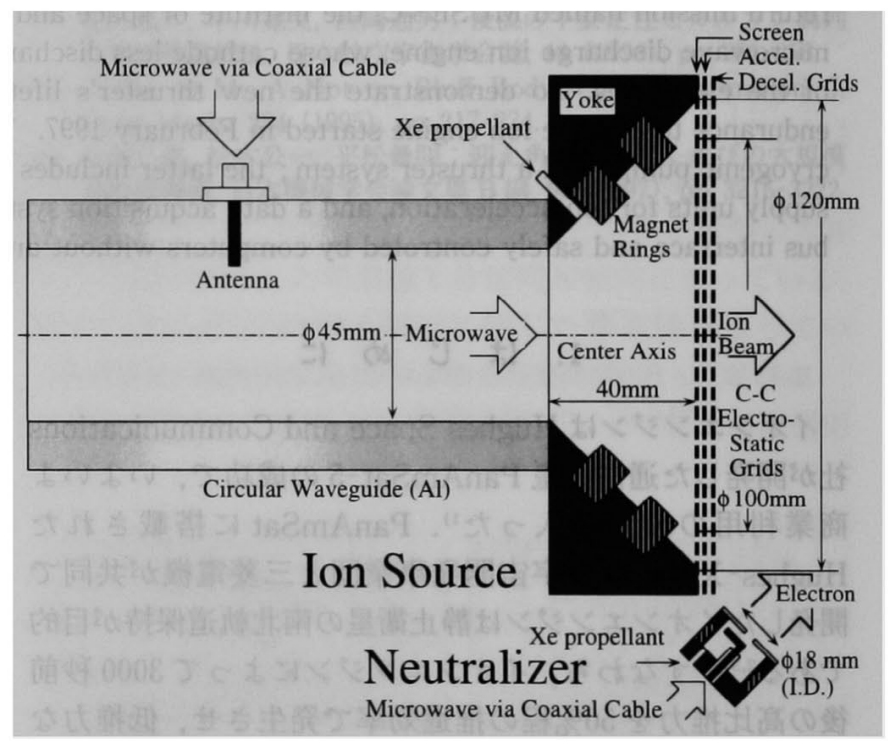

第2図 エンジニアリングモデル（EM） スラスタヘッド

の極めて強い磁場の中で電子サイクロトロン共鳴によるマ イクロ波放電が起きる8 ングは，同軸導波管変換器の形状を最適化することで行っ た．スラスタヘッド1台あたりのノミナルのビーム電流

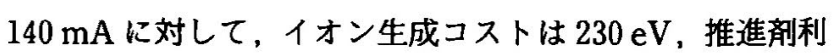
用効率は $87 \%$ となっている ${ }^{91}$.ここでイオン源の生成コス トはビーム電流を放電室へのマイクロ波投入電力 $32 \mathrm{~W} て ゙$ 割って計算した. 放電室の最適化が進むことで, エンジン 性能は同電力クラスの直流放電型と肩を並べるまで向上し ている(10).

プラスマからイオンを引き出す静電加速電極はカーボ ン・カーボン (C/C) 複合材に穴開け加エして作成し た ${ }^{11)}$. 各グリッドの厚さは $1 \mathrm{~mm}$, 穴数は抢よそ 700 個, ピーム有効径は $100 \mathrm{~mm}$ である.スクリーン・加速・減 速電極恃それぞれ，直径 $3 \mathrm{~mm}$ で開口率 $67 \%, 1.8 \mathrm{~mm}$ で 24\%，2.5 mm で46\%となっている. 加電圧はスクリ ーングリッドが $1500 \mathrm{~V}$, 加速電極がー300 V, 減速電極が 
0Vである. C/Cグリッドでは金属グリッドと異なり熱嘻 張率がほとんど無視できる。一方，モリブデンなどの金属 グリッドでは熱膨張によるグリッドのひずみを緩和するた め,グリッドを湾曲して配置し，グリッド支持部は特殊な ストレスリリーフ構造を持っている(2). C/Cグリッドで はそのような配慮は不要であり，平面状のグリッドを絶縁 材を介し支持リングにトルク締めすることで約 $0.5 \mathrm{~mm}$ のグリッド間隔が保たれる。

一方中和器ては，約 $10 \mathrm{~W}$ のマイクロ波が L 字型アンテ ナにて直接強磁場の中へ投入され，カットオフを越える高 密度プラスマが生成される，中和器は定電流制御されてお り、電子はおよそ $40 \mathrm{~V}$ のコンタクト電圧で主イオンビー ムとカップルする. システムを電気的に見ると，ビーム加 速電圧と等しいスクリーングリッドと放電室は衛星構体に 対して $1.5 \mathrm{kV}$ ハイイアスされている。一方、マイクロ波電 源や流量制御器は衛星構体にグランドされているため, こ れらは放電室とのインターフェース部分で直流的に絶縁さ れなければならない。このため, マイクロ波は直流成分を 遮断するDCカッターを介して放電室へ供給され，また， ガス配管は放電室との接合部に絶縁構造を持たせてある.

マイクロ波放電型放電室では直流放電に不可避ないくつ かの寿命要因を排除することで長寿命化を狙っている．ま ず，放電室内部にホロカソードを持たないため，ホロカソ ード起因のコンタミが完全に排除できる．また，イオンエ ンジン放電室内及びスクリーングリッドがエンジンと同電 位であるため, 放電室壁面はイオンのスパッタを受けな い. 更に，マイクロ波導入部となるアンテナはプラズマ生 成部から十分遠くにあるので, 主プラズマと干渉しない. これらはエンジニアリングモデル (EM) の性能評価試験 や耐久試験をとおして検証していく項目である。ただし， こうした放電室内の劣化機構を除いたとしても加速電極の 劣化機構は依然として残る。すなわち、主ビームイオン と, ピームイオンが背景の中性粒子と衝突後低エネルギー イオンとして加速電極を攻撃する電荷交換イオン, 以上 2 種類のイオンによるスパッタで, 加速電極は徐々に削れて いくことになる. 更にもう一つ覞念されるのが中和器の少 化であり, 負にパイアスされた中和器各部はイオンのスパ ッ夕を受ける，加速電極・中和器とも，単体での劣化特性 は既に評価されており，いくつかの加速試験から C/Cグ リッドはモリブデンに比へて倍以上の耐スパッタ性を持 ち，数万時間に渡る動作が期待できること ${ }^{13.14) ， ま た ， 中 ~}$ 和器についてもバイアス電圧を $40 \mathrm{~V}$ 程度とすることでス パッタの閶值を下回り，エロージンはほほ0になること が予想されている15)。しかし，エンジン全体としては今回 実施される長期耐久試験にて初めて実時間評価されること になる。

新規開発となるイオンエンジンヘッド部分は EM/PM/ FM の 3 段階で行う．EMフェーズでの目的は，1）機械 的電気的インターフェースを確証し, 基本性能を評価する
ことで，PM/FM 設計に必要な情報を得ること，2）実時 間耐久試験を行うことで，加速電極の劣化量を測定し，ま た，エンジンの性能劣化を評価すること，3）エンジン長 期運用時の不具合があればこれを見つけ出し，改善策を $\mathrm{PM} / \mathrm{FM}$ 設計にフィードバックさせること，の3 点であ る.

\section{3. 而久試験装置}

耐久試験は宇宙での真空環境と熱環境を模擬する真空夕 ンクの中で行われた．タンク内部には EM スラスタヘッ ドや中和器などから構成されるイオンエンジンが配置さ れ，推進㓮，マイクロ波と加速電圧はフィードスルーを介 して真空タンク中のエンジンに供給される(第 3 図).エ ンジン駆動系は、マイクロ波電力供給系，イオンビームを 加速する加速電源系, $\mathrm{Xe}$ ガスを供給する推進剤供給系, そして全体をコントロール・監視する測定制御系からな る.

3.1 真空装置 真空装置は第 4 図に示されるように直 径 $2 \mathrm{~m}$, 長さ $5 \mathrm{~m}$ のメインタンクと直径 $80 \mathrm{~cm}$ の二つの サブタンク, 計測用の補助タンク群から構成される.主タン クはロータリーポンプ, メカニカルブースターポンプ, タ 一ボ分子ポンプで粗引きされた後, 主タンクに直付けされ た直径 $80 \mathrm{~cm}$ のクライオポンプ ULVAC CRYO-U $30 \mathrm{H}$ 4 台にて排気される.クライオポンプ内部には液体へリウ ムを循環させており，クライオパネルは $20 \mathrm{~K}$ 以下の低温 に保たれ，このパネル上にガス吸着させることで無負荷時 で $1.3 \times 10^{-4} \mathrm{~Pa}$ 以下, Xe 流量 $8 \mathrm{sccm} に て 4 \times 10^{-4} \mathrm{~Pa}$ 以 下の真空度を維持できる.ここで $\mathrm{sccm}$ は $0^{\circ} \mathrm{C}, 1$ 気圧で のガス流量を $\mathrm{ml} / \mathrm{min} て ゙$ 示したものであり，Xe $1 \mathrm{sccm}$ は $9.8 \times 10^{-8} \mathrm{~kg} / \mathrm{s}$ に相当する. 副タンクと各種タンクはそれ ぞれロータリーポンプとターボ分子ポンプで独立に排気可 能であり，一定真空度へ達した後にゲートバルブにて主タ ンクへ接続されることになる. 主タンクは年に2〜3回の 定期メンテナンス時以外はリークせず，1 年中稼働し続け

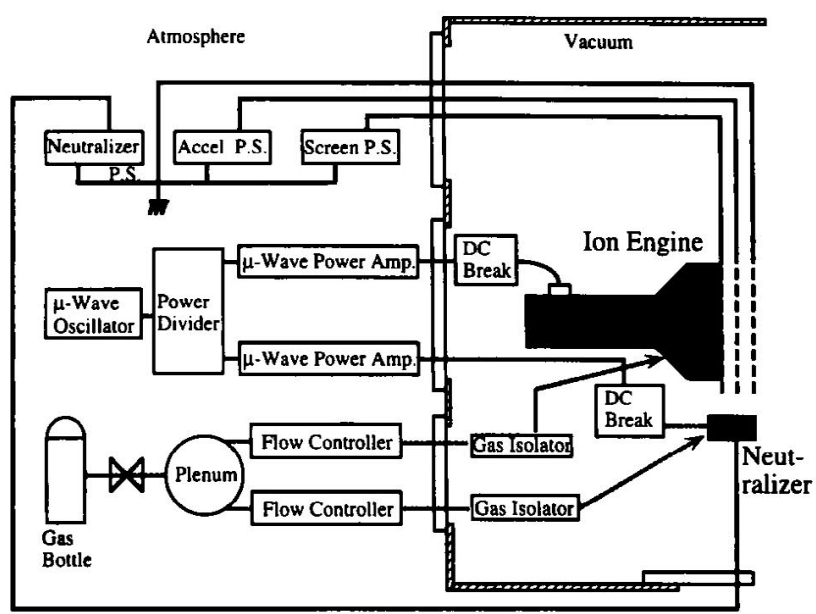

第 3 図 イオンエンシン耐久試験のハードウエア構成 


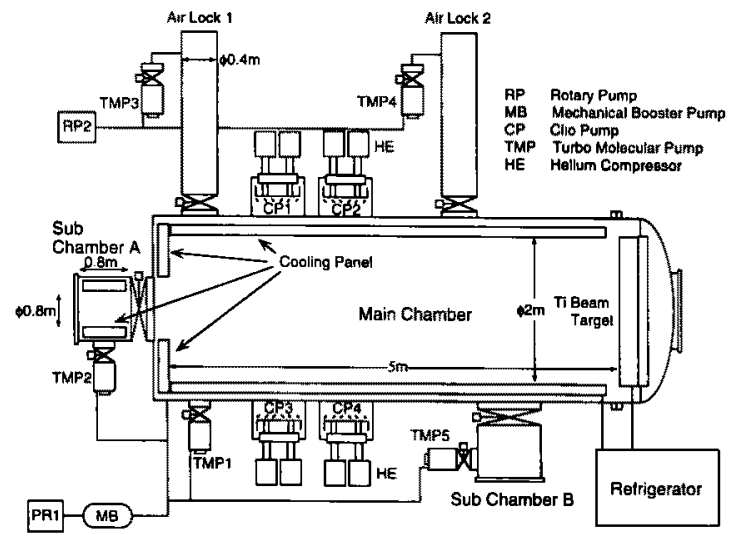

第 4 図 真空排気装置

ることになる。その間の真空装置系の動作状況は全て DELL 社製コンピュータ GXM 5100 上で動くオートメー ションソフトウェア FIX DMACSにて監視・制御されて いる.

主真空槽にはその内径と同じサイズの開閉扉が第 4 図の 右端に一つ備えられており，そこにチタン製ビームダンパ 一を設置している.クライオパネルへの輻射を防ぐため, また，宇宙での輻射環境を模擬するため，チタン製のビー ムターゲットとタンク内面を覆うシュラウドパネルはフレ オン冷却系にてー30 Aタンクに据えつけられ，イオンビームの大部分はビー ムターダットに衝突してその熱は冷却系で回収される．ビ 一ムダンパーは入射するビームに対して 20 度以下の迎え 角になるような多フィン構造を持ち，イオンスパッタリン グの総量は増大するが，供試体であるエンジンの方向に放 射されるコンタミネーション量を軽隇する効果がある。そ れにもかかわらず大きなチタンスパッタがエンジン付近に て観測され、イオンエンジン本体やエンジンをマウントす るプレート上へ堆積するのが観測された。

各種計測機器を主真空槽へ導入するため，2 軸トラバー ス装置を内蔵する大エアロック室を主真空装置上面に二つ 備えている.内蔵トラバース装置にて垂直方向に $190 \mathrm{~cm}$, 水平方向に $30 \mathrm{~cm}$ の範囲で主真空槽内の任意の位置にセ ンサを移動できる。これは主にビームプロファイルの測定 に用いられる。.また主真空槽の壁面に取りつける小エアロ ック室も測定環境を提供でき，2価イオン測定用 EXB プ ローブが装着される。

3.2 エンジン駆動系 推進郕供給系, マイクロ波電 力, 直流電力供給系が敷設され、 $\mathrm{EM}$ 試験ではこれらの各 装置は全て既製品で用意したうここれは，エンジンヘッド以 外は全てフライト実績のある部品にて構成できるためであ り，EMフェーズではエンジンヘッドとマイクロ波部品の 一部のみ製作・試験した。エンジンはワークステーション からの自動運転と, 手動運転の二つのモードで動作する。 以下では第 3 図に示してあるハードウエアの構成について 説明する。
3.2.1 推進剤供給系 Xeガスの供給にはエステック 社製マスフローコントローラを用いた。コントローラの上 流圧はガス圧コントローラで $1 \mathrm{~atm}$ 程度に制御されてお り，イオン源と中和器にはそれぞれ別系のマスフローコン トローラで流量制御する．イオン源と中和器はそれぞれバ イアスされるため, ガスアイソレーターにて絶縁されてい る.なお，フライトで採用されるのはアナログ流量制御器 ではなく，上流側タンクの圧力と温度を一定範囲内に保つ ことでオリフィス下流の流量を制御するデジタル流量制御 器であり ${ }^{16)}$ ，この場合はガス分配器によりエンジンと中和 器に一定比で分配供給される。このデジタル流量制御器に ついては別途機能モデルを製作し， EM エンジンヘッドと の喚合せ試験を行ってある.

3.2.2 マイクロ波電力供給系 水晶発振器からのマイ クロ波出力をアンプで増幅後, DCカッターを介してイオ ン源と中和器へ供給する。発振器では $4 \mathrm{GHz}$ 帯のマイク 口波を $1 \mathrm{MHz}$ 精度で周波数制御可能であり，その信号は イオン源用, 中和器用, レファレンス用の三つに分けられ る.イオン源用のマイクロ波電力は $\mathrm{R} \& \mathrm{~K}$ 社製の半導体 アンプで最大 $50 \mathrm{~W}$ まで増幅された後, フィードスルー, フレキシブルケーブルを介して DCブロックへ入力され る.このうち真空タンク内に配置される各パーツは $\mathrm{EM}$ 品で構成している．中和器側では富士通 HPA-2 マイクロ 波アンプにて、約 $10 \mathrm{~W}$ のマイクロ波電力を、これもDC ブロックを介して供給される、レファレンス用のマイクロ 波信号は周波数コンバーターで $\mathrm{RF}$ 帯へ変換後アドバンテ スト社スペクトラムアナライザーR 4131 Dにてモニター される。

3.2.3 直流電源系 直流電源はグランドに対してスク リーングリッドを+1.5 kVk，加速電極を- $300 \mathrm{Vk，}$ 中和器を $-40 \mathrm{~V}$ 程度にバイアスさせる。このうちスクリ ーンと加速電極バイアスについては定電圧制御を行い, 直 流電源としてはスクリーンバイアス電源に松定 HEL 1.5 $\mathrm{P} 250(1.5 \mathrm{kV} / 250 \mathrm{~mA})$ を，加速電極バイアス電源には 高砂 GPO 350-05（350 V/500 mA）を用い, 出力は高圧 用フィードスルーを介してグリッド端子と接続される。 な お, 中和器バイアス電源についてはスクリーン電圧と同量 の中和器電流を流すよう定電流制御される.

3.3 測定制御系 測定制御項目は, イオン源と中和器 への推進剤流量, マイクロ波周波数と電力,バイアス電 流・電圧, 各種バルブのオン・オフと温度や真空度の監視 など多岐にわたる。第 5 図に示したように各測定器へのイ ンターフェースはGP-IB バスで統一され，Lan/HPIB Gateway E 2050 A から 10 BASE-2 lan 経由でワークステ ーションへ取り込まれる. 各測定器はグランドからは絶縁 トランスにて、ワークステーションからは光ファイバー通 信機にて完全に絶縁して配置してある. Lan Gateway 以 下の測定器群は 2 系統用意してあり，エンジンシステムを 2 台同時に運転することが可能である. 入力データのう 


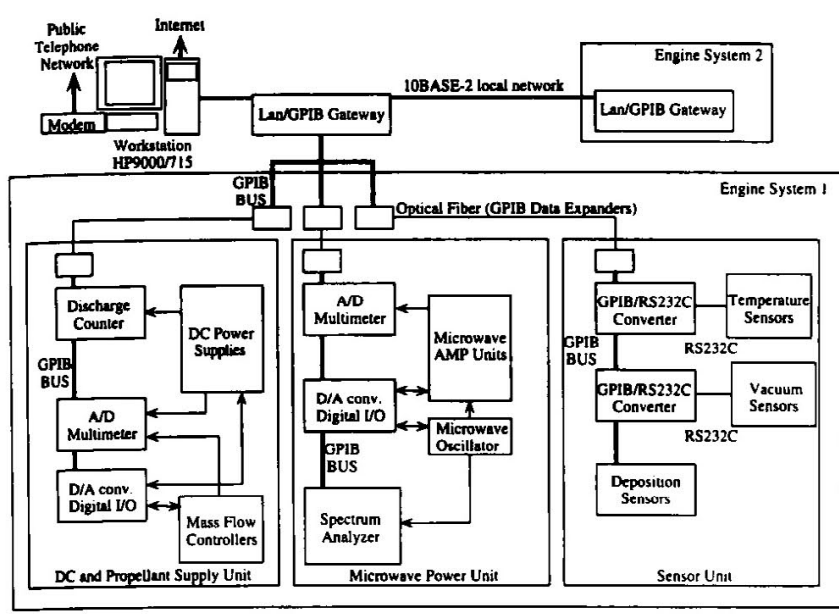

第 5 図 イオンエンジン耐久試験の計測系

ち、アナログ值については 2 台のマルチチャンネルメータ 一 HP 3457 A の 10 チャンネルマルチプレクサでスキャン した. 一方, 機器のスイッチオン・オフと機器の状態の確 認を行うデジタル入出力，およびマイクロ波電力値設定な どのD/A 出力については高砂 GP-IB コントローラ AP$1228 \mathrm{~T}$ のデジタル入出カチャンネルと $12 \mathrm{bit} \mathrm{D} / \mathrm{A}$ 出力端 子を利用した．その他にも独立した測定器として、総作動 時間カウンター, 放電カウンター, エンジンの各部に配置 された絶縁型温度計と、コンタミ計測のための薄膜センサ 一などを持っている．放電カウンターは各直流電源のア一 ク放電回数をカウントし, 温度計はエンジン各部や制御器 の発熱部に配置して通常 20〜30チャンネル, 最大で 120 チャンネルの温度データを取得する。また, 薄膜センサー INFICON IC/5 はコンタミ測定に用意されたものであり， 真空タンク各部へ配置してチタンやカーボンのコンタミ量 を測定する．真空系については専用 PCが制御している が, 電離真空計データをエンジンのコントローラであるワ ークステーション側でも直接読み込んでおり, 真空度が下 がった場合は真空系に異常が生じたと判断し，速やかにエ ンジンを停止させる. 以上のデータは約 30 秒サイクルで ワークステーション側にサンプリングされ，予め用意され た作動データテーブルと比較したうえ異常がないかどうか 判定される.

耐久試験は 1 年以上の連続作動になる。これを有人監視 によって実現するのは事実上不可能であり，エンジン各機 器の制御, デー夕処理, データ保存は一元的に Hewlett Packard 製 UNIX ワークステーション HP 715/66にて管 理され、試験は完全に無人自動にて行われる。ワークステ ーションは停電等の非常時において警報を出した上で安全 な状態でエンジンと自分自身をシャットダウンさせること ができる．また，完全なマルチタスク OSのもと，エンジ ンの運転プログラムとデータ解析，データのバックアップ などを並行して行うことが可能である（第 6 図）。更に， 安定したネットワーク機能を利用することで，インターネ

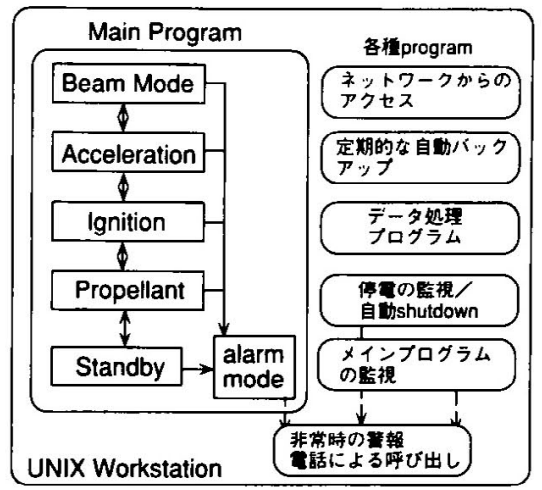

第6図 イオンエンジン制御ソフトウエア

ットまたは電話回線を利用した完全なりモート監視と遠隔 操作が可能となった，現在では日常の動作チェックをイン ターネット経由で行うだけでなく，別サーバーを経由して 試験状況をインターネット上で公開している17).たたし， インターネット経由の不正侵入を防ぐためにエンジンコン トローラのアドレスは公開せず，また，通信時は SSLゃ $\mathrm{SSH}$ といった最新の暗号通信技術 ${ }^{18)}$ を活用することで盗 聴を防いでおり，万全のセキュリティー対策を施してあ る.このような試験の完全自動化はマンパワーの節約が第 一義であるが, インターネットを介したエンジンのリモー ト運用は, インターネットネットワークが衛星の通信系バ スに置き替わったたけの，実際のエンジン運用状況と非常 に良く似た孤立した系をつくりだす。これによって，ハー ドウエアのみならず駆動ソフトウエアのロジックも併せ た，エンジンシステム全体の信頼性を検証する機会をつく ることができる。

3.4 制御ロジック エンジンの運用状況は動作モード から判断される。動作モードとしては第 1 表のように 6 つ のモードを定義した．第 6 図に示されるように，エンジン の作動はスタンバイモードから始まり，全ての装置の電源 をオンして動作確誌を行った後に, 推進剤の供給を開始す るプロペラントモードへ移行する．その後はプラズマの点 火を行うイグニッションモード，イオンビームの加速を行 うアクセラレーションの各モードを経て，最終的にはビー ムモードを維持する．各モードでは動作パラメータの設 定・デー夕収集と保存を行うと共に，監視データ項目に対 してリミットチェックが施され，異常がある場合はモード を一つ下げて対処する，最下位に位置するのがアラームモ ードであり，機器の故障やモード間の頻繁な行き来などを 検知した場合にエンジンを緊急停止して一般電話・携帯電 話に緊急呼び出しをかける。

\section{4. 初期試験結果}

4.1 エンジンのスタートアップ 自動制御によってエ ンジンが起動する模様を第 7 図に示した、エンジンはスタ ンバイモードからスタートし，プロペラントモードにて推 進剂を供給開始した後, 直ちにイグニッションモードへと 
第 1 表 イオンエンジンの動作モード

\begin{tabular}{|c|c|}
\hline 動作モード & 処 \\
\hline スタンバイ & $\begin{array}{l}\text { エンジンシステムの待機. } \\
\text { ガス, マイクロ波，電圧の出力は無し. }\end{array}$ \\
\hline プロペラント & ガスの供給あり．マイクロ波, 電圧出力は無し。 \\
\hline イグニッション & $\begin{array}{l}\text { ガス，マイクロ波，中和器バイアス電源の出力あり． } \\
\text { スクリーン/加速電極電源電圧出力無し. } \\
\text { プラスマの点火. }\end{array}$ \\
\hline $\begin{array}{l}\text { アクセラレーション } \\
\text { ピーム }\end{array}$ & $\begin{array}{l}\text { スクリーン/加速電極電源電圧をソフトスタートさせる. } \\
\text { ガス, マイクロ波, 電压の出力あり. } \\
\text { ビームモードを維持. }\end{array}$ \\
\hline アラーム & $\begin{array}{l}\text { エンジンシステムの作動を停止, 安全処理. } \\
\text { ブザーを鳴らす. } \\
\text { 管帯電話, ポケットへルにて人員の呼び出し. }\end{array}$ \\
\hline
\end{tabular}

移行する、プラズマの点火はマイクロ波投入電力に対する 反射電力の比で判断される。点火に失敗した場合, 放電室 八投入されたマイクロ波は全反射になるためである、プラ ズマ点火に問題が無ければ次のアクセラレーションモード へ移行する．アクセラレーションモードではスクリーン， 加速電極間電圧を徐々に上昇させ，モードの終わりでは所 定のビーム電流を達成する，第 7 図のように起動直後はア ーク放電や電流值のオーバーシュートのため動作が不安定 であるが，始動後数ステップでほほ定常運転に入り，ほほ 定常的にビームモードを維持することが出来るようにな る.このように流量制御器と各電源をスタートした後即座 にスタート出来るのがマイクロ波放電型イオンエンジンの 特徵の一つである．起動後約 1 時間経過するとスラスタの 大部分, 更に 2 時間経ってプレートや導波管部分も完全に 熱平衡状態に達するが, 放電部の温度は最大で $110^{\circ} \mathrm{C}$ 程度 であり，エンジンの動作限界温度を定める SmCo 磁石の 温度臨界值には十分余裕がある。

4.2 EM 耐久試験 耐久試験は BBM スラスタヘッド に加速電極を装着したグリッド先行評価試験から始められ た.これは，いくつかの予備試験や数値解析によるグリッ ドの寿命予測結果は良好だった ${ }^{19)}$ とはいえ，加速電極の スパッタ損耗はエンジンの寿命を決める重要なパラメータ であり，その耐久性は最大の関心事であったためである. 従って第 8 図のグリッドアセンブリがスラスタヘッドの他 の EM 部品に先行する形で手配された，グリッド先行試 験開始後 2500 時間を経過したところで現在の EM スラス 夕の全パーツが納品され, その後は EM コンフィグレー ションで試験が続けられている. 第 9 図は耐久試験中のイ オンエンジンである. エンジンは直径 $60 \mathrm{~cm}$ のプレート 上に設置されており，その中央にはシールドケースに囲ま れたイオンエンジンのグリッド部分が，また，左上には中 和器が点灯している様子が見える．EM スラスタヘッドは 1 台しか存在しないため, 計量以外の理由でも耐久試験は 何度か停止している。こうした停止期間中に行われたスう スタヘッドの試験項目は，1）推進性能データの取得，2） 熱真空試験及び熱サイクル試験，3）振動試験，4）放電に 用いるマイクロ波周波数を決定するためのチューニング，
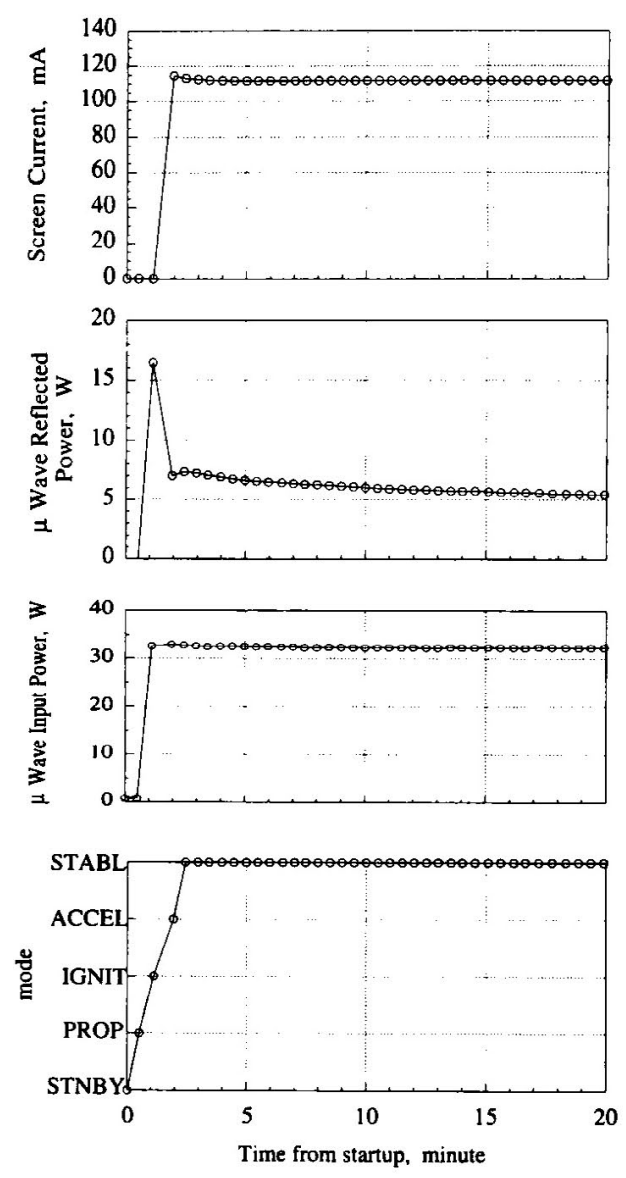

第 7 図 イオンエンジンのスタートアップ

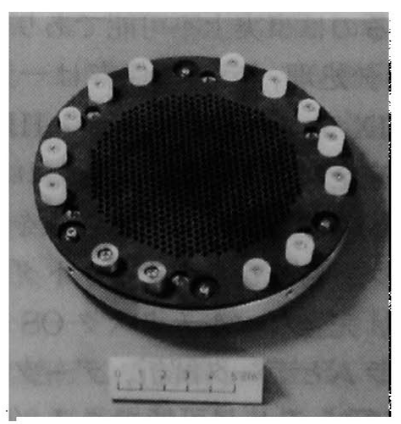

第 8 図 グリッドアセンブリ 


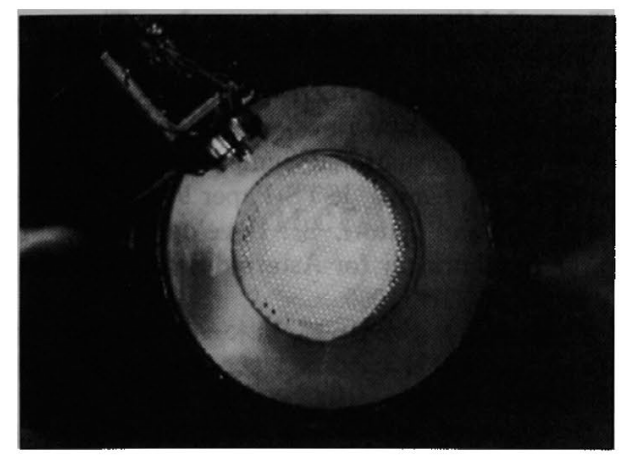

第 9 図 耐久試験中のイオンエンジン

第 2 表 EM 耐久試験のエンジン動作パラメータ

\begin{tabular}{ll}
\hline スクリーン電極電压 & $+1.0 \sim 1.5 \mathrm{kV}$ \\
加速菴檕電压 & $-300 \mathrm{~V}$ \\
減速電極電压 & GND \\
ビーム電流 & $>100 \mathrm{~mA}$ \\
アクセル電流 & $<1 \mathrm{~mA}$ \\
マイクロ波周波数 & $4.2 \mathrm{GHz}$ \\
マイクロ波電力 & イオン源 $<35 \mathrm{~W}$, 中和器 $<8 \mathrm{~W}$ \\
Xe 流量 & イオン源 $1.15 \sim 2.35 \mathrm{sccm}$ \\
& 中和器 $0.29 \sim 0.59 \mathrm{sccm}$ \\
真空度 & $<10^{-5}$ Torr \\
\hline
\end{tabular}

5) デジタル流量制御器機能モデルとの吘合せ，などであ り、これらは $\mathrm{PM} / \mathrm{FM}$ 設計を固めるために必要なデータ である。これら一連の試験と真空装置の定期メンテナンス の必要性から，耐久試験の実質的な可動率は $80 \%$ 程度と なっている．耐久試験中の動作パラメータを第 2 表に示し た.

4.3 耐久試験評価 試験では数千時間毎に分解し各部 の計量を試みる．放電部磁気回路は分割が難しいため, 各 グリッドの計量が中心になった。初期 1000 時間でのグリ ッド損耗は、スクリーングリッドについては增減無し，加 速電極は $0.2 \mathrm{mg} / \mathrm{h}$ 以下であった．逆に減速電極ではビー

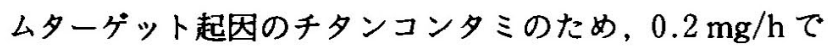
増加した. 最も心配されていた加速電極ですら椇耗は目視 では確認できない程小さかった、スラスタの設計寿命であ る 18000 時間の耐久試験が終わるまで確証こそ持てないも のの,グリッドエロージョンによって寿命が制約される心 配は無いと予想している.今後の試験にて，C/Cグリッ ドの高い耐スパッタ性を実証できると期待している。な お，放電室内のコンタミは見られなかったため，このエン ジンが放電室内に污染メカ二スムを持たないことが確認さ れた。

現在エンジンは順調に寿命評価のための耐久試験を続け ている。しかし，エンジンの初期立ち上げ時にはいくつか 不具合が見つかり，直ちに改善を行った．

1）イオン源へのマイクロ波電力供給を直流的に絶縁し ている DCブロックの絶緑破壊があった. 今回用いた DC ブロックの構造は同軸ケーブルと類似しているが，マイク 口波のみを通すために DC プロック位置では中心導体も外
部導体も絶縁シートにて絶縁されている，耐圧能力を向上 させるために絶緑シート材質を見直し，また，DCブロッ ク位置が極端な高温にならないように熱対策を施した。

2）ビームターゲット起因のチタンコンタミによる放電 室とエンジンマウント用プレート間の絶緑破壊があった。 コンタミが心配される箇所は絶縁対策を施した。

3）温度センサー等測定系センサーの故障が発生し, エ ンジンの不良と関係なく試験が中断したことがあった。

4) RS-232 C P BCD から GPIB へのデー夕変換機器を 多用した結果, 試験初期にはデー夕通信エラーが多発し た．問題のある装置を特定し，ハードウエアとソフトウエ アの両者について改善を重ねることで対処した。

$$
\text { 5.おわりに }
$$

マイクロ波放電型イオンエンジンの長期耐久性評価に必 要な無人試験システムを構成して実時間耐久試験を開始し た。初期立ちあげ試験にて，EM スラスタを含む全体シス テムの稼働・イオンエンジン制御ロジック・エンジンへッ ドの熱的特性・エンジンの推進性能などを確認し, フライ トモデルの設計に必要な情報を取得した。初期 1000 時間 の試験データを見る限りではグリッド損耗は非常に小さ く、また，スラスタ内部におけるコンタミは全く観測され ないことから，1 万時間を超えるような長期運用にも十分 耐えられそうである. 耐久性と信頼性の向上のため放電室 内から一切の污染源を排したマイクロ波イオンエンジンの 設計思想が功を奏したといえる. 逆に周辺部品にはいくつ かの問題が発生した，例えば，マイクロ波を直流的に絶縁 しているDCブロックの絶緑破壊や，ビームターダットか らのチタンコンタミが原因の絶緑破壊などである．このう ち DCブロックについては耐熱性耐圧性の強化を行い, ま た，チタンコンタミが高電位差部位に降りかからないよう 対処した，耐久試験はこのような不具合箇所の検出に大き く役立っており, 改良点の全ては今後のエンジン設計にも 反映される、グリッドを中心とする EM 耐久試験は現在 も実施中であり，合計 18000 時間の耐久性を目指して実時 間試験を続ける予定である。

耐久試験用真空チャンバーの設計・製作にあたってい ただいた日本酸素(株)殿に謝意を表します。また， MUSES-C 搭載用イオンエンジンの開発を担当される日 本電気(株)殿, 三菱重工業(株)殿のご協力に深く感謝いた します。

\section{参 考 文 献}

1) Randolph, T. and Burton, R.: The Year in Review/Electric Propulsion, Aerospace America, 35, 12 (1997), p. 49.

2) Beattie, J. R., Williams, J.D. and Robson, R. R. : Flight Qualification of an 18.mN Xenon Ion Thruster, 23rd International Electric Propulsion Conference, Seattle, IEPC Paper 93-106, 1993. 
3）梶原堅一，長野 寛，西田英司，後藤祥史，河内宏道：技術試験衛 星VI型（ETS-VI） イオンエンジン装置の開発, 日本航空宇宙学 会誌, 46 (1998), pp. 168-174.

4) Brophy, J. R. and Noca, M. : Electric Propulsion for Solar System Exploration, J. Propulsion and Power, 14 (1998), pp. 700-707.

5) Christensen, J. A., Freick, K. J., Hamel, D. J., Hart, S. L., Novenberg, K. T., Haag, T. W., Patterson, M. J., Rawlin, V. K., Sovey, J. S., Anderson, J. R., Becker, R. A. and Polk, J. E. : Design and Fabrication of a Flight Model $2.3 \mathrm{~kW}$ Ion Thruster for the Deep Space 1 Mission, AIAA Paper 98-3327, 1998.

6) 宇宙科学研究所：MUSES-C 㖕画概要, 1996.

7) 北村正治, 竹ケ原春貴：イオンエンジンの現状と展望, 日本航空 宇宙学会誌, 46 (1998), pp. 138-145.

8）國中 均：無電極マイクロ波放電式イオンスラスタの研究・開 発, 日本航空宇宙学会誌, 46 (1998)，pp. 174-180.

9) Kuninaka, H., Satori, S., Funaki, I. and Toki, K. : Endurance Test of Microwave Discharge Ion Thruster System for Asteroid Sample Return Mission MUSES-C, 25th International Electric Propulsion Conference, Cleveland, IEPC Paper 97137, 1997.

10) Patterson, M. J. : Low-Power Ion Thruster Development Status, AIAA Paper 98-3347, 1998.

11) Kuninaka, H., Satori, S. and Horiuchi, Y.: Continuous Opera- tion Test of Microwave Discharge Ion Thruster System, AIAA Paper 95-3070, 1995.

12) Kitamura, S., Miyazaki, K., Hayakawa, Y., Yoshida, H. and Akai, K.: Research and Development of $150 \mathrm{mN}$ Xenon Ion Thrusters, 21st International Symposium on Space Technology and Science, Omiya, ISTS Paper 98-a-2-11, 1998.

13) Kuninaka, H. and Satori, S.: Development of Microwave Discharge Ion Thruster for Asteroid Sample Return Mission, AIAA Paper 96-2979, 1996.

14）佐鳥 新, 國中 均, 都木恭一郎, 船木一幸, 清水幸夫, 栗木恭一： MUSES-C マイクロ波イオンエンジンの試験，第 41 回宇宙科学 技術連合螣演会, 97-11-3, 1997.

15）國中 均, 清水幸夫：マイクロ波放電式中和器の加速耐久試験, 平成 10 年度宇宙輸送シンポシウム, 1998.

16) Kuninaka, H., Funaki, I., Toki, K., Shimizu, Y., Kuriki, K. and Satori, S.: Development Status of Microwave Ion Engine System for MUSES-C Mission, 21st International Symposium on Space Technology and Science, Omiya, ISTS Paper 98-a-29, 1998.

17）インターネットホームページ: http://www.ep.isas.ac.jp/open

18）Open Design 增刊号, No. 14，暗号技術によるセキュリティの実 現, CQ 出版社, 東京, 1998.

19）白石卓也：イオンスラスタのグリッド耐久性, 東京大学大学院修 士諭文, 1995 . 